\author{
Andris Teikmanis
}

\title{
TOWARD MODELS OF SOCIALIST REALISM
}

\section{INTRODUCTION}

Researchers of the Latvian art of the Soviet period, like all researchers of the Soviet art, cannot avoid questions of political engagement of art and artists. Different binds between art and politics have been distinguished across the history of art, however, it was the Soviet Union that carried out full extent of political engagement by institutional, social and political instruments and elaborated the Socialist Realism theory that reasoned such engagement. Although political engagement of art in the Soviet Union is widely acknowledged, it is usually taken for granted. Alternatively, using semiotic approach might allow the elaboration of models of political engagement that can be applied to analyze Soviet period art and Soviet period Latvian art specifically.

\section{SHORES OF SOCIALIST REALISM}

While one might expect otherwise, conceptual frameworks of Socialist Realism are still unclear. Even brief mention of popular definitions of Socialist Realism would prove significant conceptual dispersion: "A Marxist aesthetic doctrine that seeks to promote the development of socialism through didactic use of literature, art, and music"1; "Socialist Realism, officially sanctioned theory and method of literary composition prevalent in the Soviet Union from 1932 to the

DOI: http://dx.doi.org/10.12697/BJAH.2013.6.04

1 The American Heritage Dictionary of the English Language (Boston: Houghton Mifflin Company: 2006), 1650. 
mid-1980"2. "A state-approved style in art or literature that celebrates the worker's life in a socialist country" 3 and "Socialist realism (acronym soc-real) is a style of realistic art, which was developed in the Soviet Union and became a dominant style in other socialist countries. Socialist realism is a teleologically-oriented style having as its purpose the furtherance of the goals of socialism and communism" ${ }^{\prime \prime}$. Obviously, something that might be interpreted as broadly as "aesthetic doctrine", "theory and method of literary composition", "style in art or literature" and "style of realistic art" hardly fits into single conceptual framework.

The lack of conceptual clarity of the Socialist Realism resulted in theoretical inconsistency already during the Soviet period. Though the first definition of Socialist Realism was published by Pravda on the eve of First All Union Congress of Soviet Writers (1934) and it settled that Socialist Realism was "the basic method of Soviet literature and literary criticism" that demands "truthfulness" and "historically concrete depiction of reality in its revolutionary development", a clear and unambiguous formulation of Socialist Realism was not elaborated even in the early 1980s. The term "Socialist Realism" was used: "1) as a description of a new stage in the development of art in the world, as a specific trend in the art (analogous to Critical Realism in the art of the $19^{\text {th }}$ century); 2 ) as a description of the basic method of contemporary Socialist art; 3 ) as a synonym for the concept "Socialist art"; 4) as a description of the style of Soviet literature". ${ }^{5}$ As late as in 1988 Viktor Vanslov claimed the necessity to reformulate the whole notion of Realism defining it as a particular relationship between reality and truth: "Realism is a true (truthful) depiction (presentation) of what is real (reality) in images of art (forms of art)." ${ }^{\prime}$ A supposed link between Realism and truthfulness allowed Vanslov not only to interpret Socialist Realism as a historically new type of Realism, while avoiding any direct context of style, but also to review the truth of life and the truth of art under

2 Encyclopeedia Britannica (Chicago: Encyclopædia Britannica, 2008), DVD edition 2008, also online edition, http://www.britannica.com/EBchecked/topic/551721/Socialist-Realism (accessed 1.10.2013). 3 Random House Kernerman Webster's College Dictionary, http://www.randomhouse.com/features/rhwebsters (accessed 1.10.2013).

4 Socialist Realism, http://en.wikipedia.org/wiki/Socialist_realism (accessed 1 10.2013).

5 Pēteris Zeile, Sociālistiskais reālisms (Riga: Liesma, 1981), 49.

6 Viktor Vanslov, Chto takoe socialisticheskij realizm (Moscow: Izobrazitelskoye isskustvo, 1988), 7. 
the framework of Socialist Realism. Obviously, this interpretation reinstated an orthodox assertion that Socialist Realism is Realism enhanced by Socialist ideology. At the same time Vanslov tried to modernise Socialist Realism by reinterpreting the confrontation between bourgeois and Socialist ideology in the art world through the lenses of two aesthetic ideas: the technological and the humanist conception. ${ }^{7}$ This represented one of the last efforts to find a compromise between the latest artistic developments and the dogmatic position of Socialist Realism, and to claim a new role for the Socialist Realism which might appropriate environmental concerns of the late 1970s and early 1980s.

Another characteristic attempt to modernise the Socialist Realism was demonstrated by Pēteris Zeile who sought to present an interpretation of the Socialist Realism that was far more all-encompassing and that regarded art as a complex systemic phenomenon. Zeile argued that "Latest Soviet aesthetics have thoroughly demonstrated that art offers a diverse revelation of functions including study, evaluation, creative construction, communication, education, inspiration, emotional experience, etc." ${ }^{8} \mathrm{He}$ based his claims on the interpretation of Marxism and Leninism, and (usually unnamed) representatives of the latest Soviet aesthetics. His method was, namely, "Socialist hermeneutics": a process that involves not just interpretations of text and attempts to draw close to their original purpose, but also all attempts to provide explanations other than the customary, presenting these as the results of new interpretations and translations of texts. This technique allowed him not only the adaption of assumptions expressed by other Soviet theorists, but also the proposition of diverse ideas whilst masking them as results of a more careful review of Marxist and Leninist texts.

Once the Soviet Union collapsed, researchers who had focused on a critical interpretation of the Socialist Realism traditionally ignored these latest attempts of modernisation, preferring to emphasise a more orthodox version of the Socialist Realism.

7 Viktor Vanslov, O realizme socialisticheskoj jepohi (Moscow: Izobrazitelskoye isskustvo, 1982), 50.

8 Zeile, Sociālistiskais reālisms, 20-21. 


\section{CONCEPTIONS OF SOCIALIST REALISM}

In 1994, three years after the collapse of the Soviet Union, Jeffrey Brooks argued that researchers of Socialist Realism had often highlighted either political or aesthetic dimensions of the Socialist Realism - from the one hand functions of art in national policy, links between political and cultural actors, or from the other hand interaction between art and tradition. Therefore researchers of the Socialist Realism should be divided up into two groups: those who focused on the aesthetic aspects of the style, and those who preferred to accentuate the political aspects instead. ${ }^{9}$

Though Igor Golomstock did not create the term "totalitarian art", nor was he the first to point to obvious parallels between the art of the Stalinist Soviet Union and that of the Hitler's Third Reich, his "Totalitarian Art in the Soviet Union, the Third Reich, Fascist Italy and the People's Republic of China"10 represented the purest example of the assertion to use this term to describe politically commissioned artistic phenomena in countries considered to be totalitarian. While initially this approach seemed capable, the relaying on very disputable concept of "totalitarianism" and "totalitarian countries" that were defined outside the realm of art history demonstrated not only methodological flaws of the conception of "totalitarian art" but also weakness of all politically motivated approaches. Presumably, it was the fear of being excessively dependent on the concept of "totalitarianism" in a particular historical context that determined why some researchers who have looked at the relationship between art and $20^{\text {th }}$ century undemocratic regimes in Europe have carefully avoided the terms "totalitarianism", "totalitarian country" and "totalitarian art".11

In the same 1988, when Vanslov released his "What is Socialist Realism?", Boris Groys published "Gesamtkunstwerk Stalin" that offered a radical reinterpretation not only of Socialist Realism but also

9 Jeffrey Brooks, „Socialist Realism in Pravda: Read All about It!“, Slavic Review, No. 4 (1994), 973-991. 10 Igor Golomstock, Totalitarian Art in the Soviet Union, the Third Reich, Fascist Italy and the People's Republic of China (London: Collins Harvill, 1990).

11 Art and Power: Europe under the Dictators (1930-1945), eds. David Ades, Dawn Elliott, Tim Benton (London: Thames and Hudson, 1995). A good example of this is the introduction by Eric Hobsbawn to the catalogue of the exhibition Art and Power: Europe under the Dictators (1930-1945), supported by the Council of Europe, see Eric Hobsbawm, "Foreword", Art and Power: Europe under the Dictators, (1930-1945), eds. Dawn Ades, Tim Benton, David Elliott, Iain Boyd Whyte (London: Thames and Hudson, 1995), 11-15. 
entire Soviet history. ${ }^{12}$ He proposed that not just Socialist Realism, but the entire political model created by Stalin in the Soviet Union was an heir to Avant-Garde art of the Soviet Russia. Groys substantiated his interpretation sketching total pretensions toward the transformation of aesthetic and social reality expressed by representatives of the Russian Avant-garde and drawing parallels between the these intentions, on the one hand, and the total transformation of public life, which was implemented by the Bolsheviks, on the other. This allowed an understanding that the ideological models, which these movements proposed, must be seen not as parallel manifestations, but as causal continuity. Groys interpretation of the development of Soviet art, after the death of its primary demiurge Stalin in 1953, was no less impressive. Groys argued that the end of the Stalinist myth meant the emergence of a period that was not post-Utopian, but marked by new ecologically nationalistic myth, which influenced official Soviet ideology for the next several decades. ${ }^{13}$

Boris Groys was not the only one to insist on a direct relationships between avant-garde art and Socialist Realism. Igor Golomstock also linked "totalitarian art" with the heritage of avant-garde. ${ }^{14}$ Similar idea was expressed by Ekaterina Degot' in her "Russian Art in the $20^{\text {th }}$ Century". Degot' divided $20^{\text {th }}$ century Russian art into four phases: Transcendence Project, Ideological Project, Synthetic Project, and Conceptual Project. Transcendence Project represented Russian Modernism of the early $20^{\text {th }}$ century; Ideological Project referred to the Soviet Avant-garde, Synthetic Project to late Soviet Avant-garde and the art established by Stalin, and the Conceptual Project to unofficial art in the Soviet Union from the 1960s to the 1980s. Hence Degot' viewed Socialist Realism as the second wave of the avant-garde, insisting that Realism was not directly presented inside the Socialist Realism, but was used as a sort of quote. She also wrote that the aesthetic ambitions of Socialist Realism could be directly linked to the ideas that avant-garde artists in Russia had held about ways of overcoming alienation. Socialist Realism overcame the social alienation of Modernism, the alienation between artist and his audience, the alienation of masses and the alienation between

12 Boris Groys, Gesamtkunstwerk Stalin: Die gespaltene Kultur in der Sowjetunion (Munich, Vienna:

Carl Hanser Verlag GmbH \& Co., 1988).

13 Ibid., 103.

14 Igor Golomstock, Totalitarnoe iskusstvo (Moscow: Galart, 1994), 31. 
artist and the state..$^{15}$ Also Mikhail German has argued that roots of totalitarian Romanticism could be located in the Modernism of the $20^{\text {th }}$ century. ${ }^{16}$ Such opinion coincided with the conception of "reactionary modernism" invented by Jeffrey Herf who brought it forward to describe the mixture of "irrationalism with enthusiasm for technology" that set up the way to Nazi totalitarianism. ${ }^{17}$ The modernisation of Soviet Union was driven by the same force of technological enthusiasm that inspired avant-garde artists. The acknowledgment of this allowed Groys a radical reinterpretation of Soviet history questioning the entire nature of the Socialist Realism.

Even though Jeffrey Brooks saw Evgeniy Dobrenko as one of those researchers who emphasized the political aspect of the Socialist Realism, Dobrenko's conception of the Socialist Realism was similar to that of Groys in terms of the linkage between aesthetics and politics. Dobrenko argued that the artefact of Socialist Realism was always at the shifting crossroads of aesthetic intention and politically determined interests. However, Dobrenko criticised Groys for supposedly interpreting Stalin as the demiurge of the Avant-garde and for accenting the aestheticization of politics while ignoring the main difference between politics and art, the fact that politics did not decide or seek to achieve purely aesthetic goals. Before the Socialist Realism became the aesthetics of Stalin's politics, it had to become part of those politics. By ignoring this fact, Groys has aestheticised Stalinism instead of trying to answer the question of what the aesthetic goals of this regime were. According to Dobrenko, the Socialist Realism cannot be viewed as a purely aesthetic or political phenomenon. The Socialist Realism also cannot be separated from politics and ideology, and this leads to conclusions that politics cannot be split from the Socialist Realism either. The Socialist Realism was not a decoration for Stalinist politics; it did not make political reality more beautiful nor serve as a "factory of fortune". Instead, it was the direct producer of the particular reality that was Socialism. This, wrote Dobrenko, could be characterised better by

\footnotetext{
15 Ekaterina Degot', Russkoe iskusstvo XX veka (Moscow: Trilistnik, 2000), 140-141.

16 Mikhail German, Modernizm. Iskusstvo pervoj poloviny XX veka, Novaja istorija iskusstva (Saint Petersburg: Azbuka-klassika, 2008), 354.

17 Jeffrey Herf, Reactionary Modernism: Technology, Culture, and Politics in Weimar and the Third Reich (Cambridge: University Press, 1984), 40.
} 
restating Marx's famous formula "product-money-product" as "reality-Socialist Realism-reality". ${ }^{18}$ Hence Dobrenko referred to the thought that had been expressed by Slavoj Žižek that ideology cannot be perceived as a false reality other than the reality itself must be perceived ideologically. He also adapted Jacques Baudrillard's idea of hyperreality arguing that Socialist Realism should be interpreted as something which transformed reality into reality at a higher level, a hyper-reality that is more real than ordinary reality. Socialist Realism was the specific force behind the "Empire of Signs" of the Soviet Union, the one in which "Socialism" as a denotation was replaced with "Socialism" as a designator. Dobrenko had assessed Socialist Realism not as a simply servant to political and ideological powers but as an equally valuable component, as the primary mechanism that transformed Soviet reality. ${ }^{19}$

\section{MODELS OF ENGAGEMENT}

The Great Soviet Encyclopaedia proposed that artistic method must include four corresponding elements related to the relationship structure of the art: cognition, evaluation, transformation of life, and sign expression of the artistic information thus received. The latter was described as a semiotic element "that indicates the means by which a given construct is transformed into a system of image-producing signs, or a unique "artistic language"." ${ }^{20}$ The especial emphasis was put on Socialist Realism's ability to provide the equilibration of all four components: the principle of the unity of party-mindedness (partiinost') and truthfulness (pravdivost'), the unity of reflection and artistic transformation of reality, the unity of content and form and the unity of poetic meaning and artistic language. Although the semiotic theory of Socialist Realism had not been established the proposed artistic method of Socialist Realism demonstrated that artistic language served as semiotic instrument capable of providing cognition, evaluation and transformation of reality into a higher level reality, namely Soviet Reality. The main purpose of

18 Evgeniy Dobrenko, Political Economy of Socialist Realism (New Haven: Yale University Press, 2007), 6 .

19 Ibid., 26-27.

20 Moisej Kagan, „Metod hudozhestvennyj“, Bolshaya Sovetskaya Entsiklopediya, 1969-1978, CDROM edition (Moscow: ZAO „Novyj Disk”, 2004), also accessible online, http://slovari.yandex. ru/ книги/БСЭ/Метод\%20художественный/ (accessed 1.10. 2013). 
political discourses was the delivery of models of social reality that could be applied as tools for the construction of new reality.

Any social reality offered by politicians was a product of rhetorical construction. By choosing their own rhetorical strategies politicians determined what kind of social reality would be allowed to construct and what kind of "surplus reality" would be foreclosed ${ }^{21}$ for most of the consumers of this new reality. As it was suggested by social and literary critic Kenneth Burke and repeated by political scientist Murray Edelman - it was a common function of political rhetoric to "blunt the too sharply pointed". ${ }^{22}$ The language used by politicians served as an instrument to hide not only their true intensions but also to cover certain parts of unpleasant reality. Even more, Edelman insisted that the true meaning of political language is concealed under the camouflage of styles and forms of language used by politicians. In this respect, Murray Edelman was the first to begin to study the meaning of the style and the form rather than the content of the political language. Pertti Ahonen who characterized Edelman as a scholar "who turned out to have been twenty to twenty-five years ahead in his study of symbolic aspects of politics"23 voiced that "Copernican revolution" or, in other words, decentralization and deconstruction of "positivist" political science should be one of the main goals of semiotic studies of politics. ${ }^{24}$

Keeping in mind that semiotic studies of politics were inquiries into power functions of textual practice that have to take into consideration function, role and social context of political communication rather than the content of certain political texts, it is possible to introduce semiotic studies of political images designed to investigate general rules of interaction between political texts and images rather than the content of certain politically engaged pictures. These studies should relay on rather broad tradition and interpretation of relations between texts and images. Still it was an interplay between image and text that allowed verbal translation of visual content and that caused the emerging of Ut pictura poesis

21 Richard Harvey Brown, „Textuality, Social Science, and Society“, Tracing the Semiotic Boundaries of Politics, ed. Pertti Ahonen (Berlin \& New York: Mounton de Gruyter, 1993), 43-60.

22 Murray Edelman, Symbolic Uses of Politics (Urbana: University of Illinois Press, 1968), 33.

23 Pertti Ahonen, „A Copernican revolution in political research: Reflections on the rainbow of essays in this book", Tracing the Semiotic Boundaries of Politics, ed. Pertti Ahonen (Berlin \& New York: Mounton de Gruyter, 1993), 6.

24 Ibid., 1-27. 
conception. ${ }^{25}$ According to Meyer Shapiro relationships between image and text were manifold representing various models of narrative capacity. They varied from images having only general information that could be referred to texts to images offering more interpretative material than included in texts. ${ }^{26}$ However, relations between images and texts were not marked with functions of articulations only. Describing relations between linguistic message and image, Roland Barthes noted that linguistic message performs two main functions: limiting possible interpretation of the image and ensuring consistency of visual and narrative representation. ${ }^{27}$ Therefore, linguistic message plays crucial ideological role defining the acceptable limits of interpretation and ensuring the ideological consistency of interpretations. Pictures also have their visual power or, as it was defined by W. T. Mitchell, two kinds of visual power, power of illusionism and power of realism, or in other words, power of spectacle and power of surveillance. ${ }^{28}$ Therefore, pictures used in political communication at first seemed relying on their visual power that encouraged widespread interpretations of visual turn of contemporary political practices; however, their potential political message were dependent on broader context in the same way as Edelman insisted that meaning of words depended on "social situations, experiences, ideologies and psychological needs of those who process and those who originate". ${ }^{29}$ In case of images their contextual meaning firstly would be borrowed from surrounding textual discourses. Example of such contextually constructed meaning appears in Ernst Gombrich's reflections on Thorwaldsen's "Lion of Lucerne", the memorial for the Swiss guards killed during the French Revolution, highlighting the importance of textual context of visual metaphors of value. Gombrich assumes that message carried by this memorial could be "they died like lions" or "they died, lions". ${ }^{30}$ Although "Lion of Lucerne" was a fine example of metaphor it was not a visually based metaphor. Notions of lions as powerful and courageous beings were transferred

25 György Szőnyi, Pictura \& Scriptura. Hagyományalapú kulturális reprezentációk 20. századi elméletei (Szeged: JATEPress, 2004), 13-19.

26 Meyer Schapiro, Words, Script, and Pictures: Semiotics of Visual Language (New York: G. Braziller, 1996), 13-16.

27 Roland Barthes, „Rhétorique de l'image“, Communication, nº4 (1964), 40-51.

28 W. J. T. Mitchell, Picture Theory: Essays on Verbal and Visual Representation (Chicago: University of Chicago Press, 1994), 325-326.

29 Murray Edelman, The Politics of Misinformation (Cambridge University Press, 2001), 78.

30 Ernst Gombrich, Meditations On a Hobby Horse and Other Essays On the Theory of Art (London, Phaidon Press, 1963), 12. 
from the verbal to visual language because it was not originated in the visual message itself. As it was commented by Göran Sonesson in his "Pictorial Concepts", the statement "they died like lions" or "they died, lions" could not be told apart from this sculpture and that "the example itself also suggests that it is only by being "anchored" linguistically, that is by the title, that the picture becomes a metaphor". ${ }^{31}$

As visual powers of images are a matter that politicians would like to exploit making their accounts more powerful and even more genuine, one could admit that the main role of visual discourses of politically engaged pictures is to serve as devices that overcome the discontinuity of political discourses or, in other words, as devices legitimating transgression of norms, that is rules derived from our everyday experience, introduced by political textual discourses. As practices of engagement relayed on rhetorical strategies, political pictures are not simply illustrations of political texts. Power of illusion and power of realism supplies political statements with ocular proofs and credibility. Two sources of power, textual and visual, are considered defining the first two models of dominance: a model of textual dominance that uses visual discourse of picture as a device legitimating transgression of norms (that is rules derived from our everyday experience) introduced by political textual discourse; and a model of visual dominance that uses textual discourse as a device that legitimates transgression of norms introduced by visual discourse of pictures (see fig. 1, a). Considering more complex relations of verbal and visual domination in the pictorial message this set of models can be extended. Four types of domination, verbal, visual, non-verbal and non-visual, are defined by applying Greimas's Semiotic Square (see fig. 1, b). Although the Semiotic Square grants introduction of two other models of domination, a non-textual and a non-visual one, it does not categorize latent or potential domination that can be embedded in images. Such limit has been overcome by introducing the Matrices of concepts put forth by philosopher Paul Franceschi to provide an alternative to the Semiotic Square. ${ }^{32}$ It allows an extension of the opposition from two to six categories of dominance (see fig. 1, c). These categories consist of six conceptual conditions: neutral, positive and negative dominance of

31 Goran Sonesson, Pictorial Concepts. Inquiries Into the Semiotic Heritage and Its Relevance to the Analysis of the Visual World (Lund: Lund University Press, 1989), 333-340.

32 Paul Franceschi, „Le plan dialectique: pour une alternative au paradigme“, Semiotica, vol. 146 (2003), 353-367. 
textual or visual power inside pictures that allows the construction of six models of political engagement:

- Model of positive textual dominance that uses visual discourse as a device to legitimate transgression of norms introduced by textual discourse;

- Model of positive visual dominance that uses textual discourse as a device to legitimate transgression of norms introduced by visual discourse;

- Model of potential textual dominance that can use visual discourse as a device to legitimate transgression of norms introduced by textual discourse;

- Model of potential visual dominance that can use textual discourse as a device to legitimate transgression of norms introduced by visual discourse;

- Model of negative textual dominance that imitates the use of visual discourse as device to legitimate transgression of norms introduced by textual discourse;

- Model of negative visual dominance that imitates the use of the textual discourse as a device to legitimate transgression of norms introduced by visual discourse.

Models of potential, positive and negative textual dominance constitute the most explicit cases of intervention of political discourses into pictures; they describe various stages of attempts to engage art as a propagandistic device and therefore they should be named as representing some stages of propaganda, or, in other words, as a set of Propaganda models. Cases of engagement of models of visual dominance are mainly left untold. However, it does not mean that they are rare. As it is suggested by Murray Edelman, artworks do not represent "reality", "the real world", or "everyday life". Rather, art creates "realities and worlds" and, in the same time, "political meaning of works of art" are never given, but always "“'taken", by political leaders and followers", in other words, the art simply serves "as floating signifier into which political groups read whatever serves their interests and ideologies". ${ }^{33}$ Acceptance of

33 Murray Edelman, From Art to Politics: How Artistic Creations Shape Political Conceptions (Chicago: University Of Chicago Press, 1996). 
a)
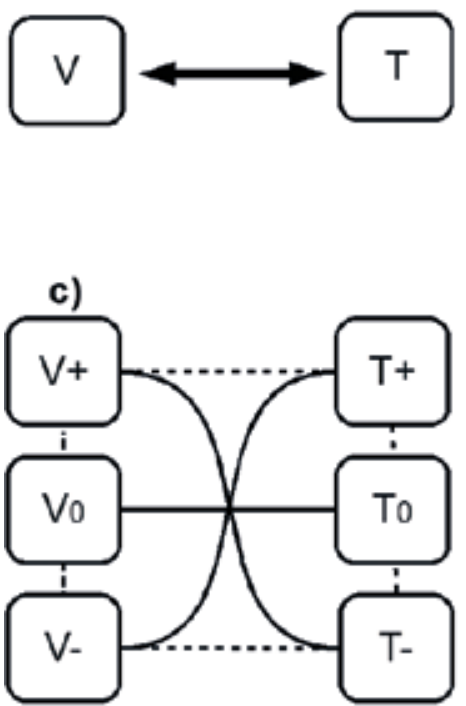

b)

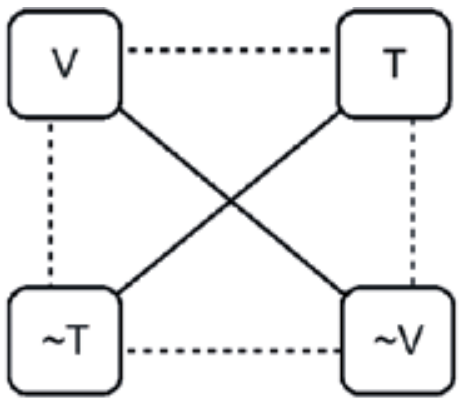

d)

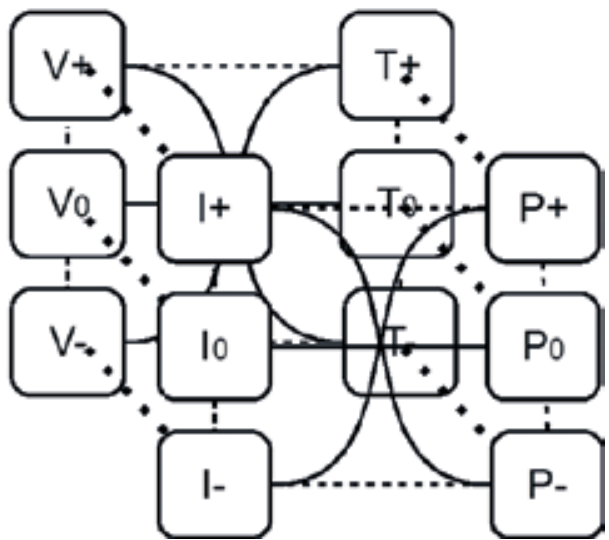

Fig. 1. Models of engagement: a) models based on basic opposition; b) models based on the Semiotic Square; c) models based on Matrices of concepts; d) the transposition of political functions of art.

$\mathrm{V}$ - positive visual dominance; $\mathrm{T}$ - positive textual dominance; $\mathrm{V}^{0}$ - neutral (potential) visual dominance; $\mathrm{T}^{0}$ - neutral (potential) textual dominance; $\mathrm{V}$ - - negative visual dominance (nontextual dominance); $\mathrm{T}-$ - negative textual dominance (non-visual dominance); I+ - ideology model; P+ - Propaganda model; $\mathrm{I}^{0}$ - proto-Ideology model; $\mathrm{P}^{0}$ - proto-Propaganda model; I- - post-Ideology model; P- - post-Propaganda model

Edelman's position that art can serve as a basis and construction means of any actual ideology as well as serve as an instrument of subversion of ruling ideologies or political discourses allows description of models of potential, positive and negative visual dominance as the constituting presence of potential, positive or negative visual ideology. Therefore these six models are named as "proto-Propaganda model", "Propaganda model", "post-Propaganda model" and "proto-Ideology model", "Ideology model" and "post-Ideology model". 


\section{MODEL OF TEXTUAL DOMINANCE (PROPAGANDA MODEL)}

The Propaganda model of engagement demonstrates an obvious case: the subordination of visual discourse of picture to political textual discourse. All power of illusionism and power of realism are used to convince viewer of trustfulness of political message conveyed by pictorial utterance. This model is used to produce the most explicit cases of visual political propaganda. Since the treatment of pictures for propagandistic purposes is a remarkably old phenomenon the presence of this model can be identified from the first known examples of the use of political art. However, it was the $20^{\text {th }}$ century when the use of this model produced the most controversial examples of political art produced under totalitarian regimes of Stalinist Soviet Union or National Socialist Germany. Moreover, speaking about cases of politically engaged art of Stalinist Soviet Union or National Socialist Germany it would be important to emphasize that the application of Propaganda model was not some individual phenomena but it was introduced by state-based institutions using all power of persuasion and enforcement and in full accordance with textually articulated ideology. Furthermore, most important characteristics of this model was its ideological framing. Socialist Realism, the theory developed in the Soviet Union that reasoned political engagement of art, was one of the most visible examples of ideological conceptualization of the role of art and artists. Because of the dominant presence of Socialist Realism in the Soviet art theory, it was reasonable to identify the whole period of Soviet art and not only some isolated cases as belonging to the Propaganda model.

As the Republic of Latvia was subjugated through the sequence of Soviet and Nazi occupations, it was easy to presume that relations between art and politics throughout the First Soviet period (1940-1941), Nazi period (1941-1944) and Stalinist phase of Second Soviet period (1944-1956) went in accordance with Propaganda model. However, closer inspection of political engagement of art reveals that, contrary to what is expected, First Soviet period represented rather unrealized attempts to implement the Propaganda model; such model was never introduced during Nazi occupation, and clear features of Propaganda model of Second Soviet period appeared only after so-called Zhdanovshchina emerged. The Resolutions from 1946 to 1948 of The Central Committee 
of All-Union Communist Party written by Central Committee secretary Andrei Zhdanov marked a pivotal point in Soviet culture politics. The 1946. Resolution of the Central Committee was directed against two literary magazines Zvezda and Leningrad and therefore did not have direct impact on artistic form other than an awkward implementation of conflictlessness proposed by Zhdanov; however, the 1948. Resolution of the Central Committee aimed at Vano Muradeli's opera "The Great Friendship" marked the beginning of the so-called Anti-formalist campaign. While this Resolution concerned the composer Vano Muradeli and was used against many Soviet Union's foremost composers it provided authorities with tools of discursive control applicable also in other fields of culture, for example, in the field of visual art. It caused the implementation of verbally dominated ideology into the content of the artwork over artistic form not only in music but also in visual arts. Using the same pretext of the necessity for creation of artworks that should be understandable to ordinary people (the principle of narodnost) the artistic form of Russian $19^{\text {th }}$ Century realists was exemplified. With its lifelike mimetic qualities, Russian $19^{\text {th }}$ Century Realism ideally suited as the form of visual discourse that could be used to legitimate transgression of norms introduced by political ideology. It was merely the artistic form of Russian $19^{\text {th }}$ Century Realism that was borrowed and not its active and socially critical position. Contrary to it, particular rhetorical devices that lied in the relations between theatricality and realism of Soviet art were conditioned. Furthermore, theatricality appeared as a dominant kind of visual manner of Stalinist Socialist Realism that featured an interplay between literary content and inflated visual mimetic of pictures. Even when the visual rhetoric of artworks of this period was carried out on the level of the pictorial (iconic) utterance, the rhetorical relations were developed as derived from the textual context.

The role of art as a constructor of Soviet political reality causes necessity to further reevaluate the notion of Realism in the considered period. The most important differences between Realism and Socialist Realism lie directly in their attitude to reality. Both utilized highly mimetic means of expression but Soviet artists were directed to construct an ideologically correct model of reality foreclosing any kind of "surplus reality" that could challenge the official interpretation of historical events, ideology or political power of the Communist Party and its actual leaders. 


\section{MODEL OF POTENTIAL TEXTUAL DOMINANCE (PROTO-PROPAGANDA MODEL)}

Contrary to expectations, the Propaganda model of Socialist Realism was accomplished significantly after the launch of the sovietisation of the Republic of Latvia. Although the First Soviet period was marked with merciless substitution of all establishments of the independent Latvian state with Stalinist totalitarian institutions, changes in the language and subject of art and the implementation of Socialist Realism were slower than one would expect comparing to other politically and ideologically contingent changes. The term of Socialist Realism was used already in autumn of 1940. An essay "Socialist Realism in Art" by Boris Vipers in 1940 demonstrated a lack of knowledge of Socialist Realism that was replaced by author's own interpretation that, although brilliant, was not grounded in the actual discourse of Socialist Realism. ${ }^{34}$ A review of "French Modern Painting" by Kristaps and Gederts Elias contained interpretations of $19^{\text {th }}$ century French art that from the point of Stalinist Era Socialist Realism could be seen as an apology of impressionism. ${ }^{35}$ Still in the summer of 1941, one year after the incorporation of Latvia in the Soviet Union, affirmative publications about two Latvian modern painters Jāzeps Grosvalds ${ }^{36}$ and Jēkabs Kazaks ${ }^{37}$ were published by the most popular tabloid.

However, alongside the failures new attempts to exercise control on artistic space through political textual discourse emerged. Despite the lack of familiarity with Socialist Realism theory considerable attention was paid to control the textual space of art. Also several compendiums of official and recommended thematic subjects concerning the politically correct interpretation of the history of revolutionary struggle and Soviet reality were published and distributed among artists by the Authority of Arts Affairs of Soviet Latvia. Therefore, the First Soviet period and beginning of Second Soviet period till 1948 can be acknowledged not as the implementation of Propaganda model but rather as an attempt to implement it and thus be identified as belonging to proto-Propaganda model. Because Propaganda model was only intended at its very early

34 Boris Vipers, „Sociālistiskais reālisms mākslā“, Karogs, novembris (1940), 437-442.

35 I.S. (Kristaps and Gederts Elias), „Franču jaunlaiku gleznieciba“, Atpūta, 8.9.1940.

36 Artūrs Jūrasteteris, „Nacionālā eposa rosinātājs glezniecībā (Jāzeps Grosvalds 1891.-1920.)“, Atpūta, 30.4.1941.

37 Uga Skulme, „Jēkabs Roberts Kazaks (1895.-1920.)“, Atpūta, 16.5.1941. 
stage of realization some inertia and presence of post-Ideology model should be recognized in this period as a continuous parallel trend.

\section{MODEL OF NEGATIVE TEXTUAL DOMINANCE (POST-PROPAGANDA MODEL)}

Even though mass political repressions ceased with Stalin's death in 1953, a relatively liberal atmosphere failed to arise because of the ideological control of the Communist Party. It was only the XX Congress of the Communist Party of the Soviet Union, marked by Nikita Khrushchev's "Secret Speech" denouncing the personality cult of Joseph Stalin and Stalinism and setting off the so-called Khrushchev Thaw, that unfolded a path toward modernisation of Soviet Culture. In 1957 new artistic movement known as the "Rough Style" (Surovyj Stilj) emerged. It represented reduced theatricality, subject-matter less straightly translatable into verbal utterance, flattened and generalized stylization of depicted reality and, what is more important, emphasis on formal qualities of visual language, which would be just unimaginable during Anti-formalist campaign a few years earlier. Despite crackdown of Moscow nonconformists in the late 1962 and ensuing campaign against Abstractionism and other manifestations of Bourgeois art, changes in the language of art became irreversible. Soviet Art lost its homogeneous language. Instead, many artistic trends flourished that were all covered under the hood of the method of the Soviet Realism. While the textual dominance seemed intact because of the institutional support of the Artist Union of USSR and widespread Aesopian references to the method of Socialist Realism in theoretical discourses by Soviet art theoreticians, the political textual dominance was no more coherent and unbroken. Political textual discourse of this Late Soviet political art was used just as an excuse to artists' visual experiments. Artists denied the expression in pure abstract forms found many other paths to give power to their visual language. This discontinuity between political and visual discourses was covered by the remains of political messages. For the subsequent almost three decades Soviet state and Soviet artists rested on this post-Propaganda model which struggled to preserve the myth of Soviet political art and to hide the fact that there was no more coherent political message that could be carried by political art. The visual 
discourse became a less effective device that could legitimize transgression of norms introduced by political textual discourse.

\section{MODEL OF VISUAL DOMINANCE (IDEOLOGY MODEL)}

While all models of political engagement employed by Socialist Realism could be attributed as based on potential, positive or negative textual dominance, opposite models of visual dominance were relationally presented and their potential and possible political roles continued some argue in absentia. It was especially true, because visual dominance did not designate any lack of political involvement. Take, for example, the $20^{\text {th }}$ century avant-garde art. It was socially and politically extremely active and engaged but it was not subordinated to any political texts. Of course, many avant-garde artists had their political views but they did not produce their art as rough illustrations or propaganda of them. In the same time "active semiosis" of avant-garde was total and revolutionary to an extent that it led art historians to assume the totalitarian state was just as sequel of the global avant-garde project. Boris Groys who was the most prominent author of such assertions stated that "the radical historical avant-garde movement can best be described as an attempt to replace the dictatorship of art consumers with a dictatorship of art producers" and it was obviously that "an aesthetic dictatorship requires a political dictatorship able to realize and stabilize any given aesthetic project" ${ }^{38}$

Groys interpreted not just Socialist Realism, but the entire political model created by Stalin in the Soviet Union as an heir to the Russian avant-garde art. He based his claims on total pretensions toward the transformation of aesthetic and social reality expressed by the representatives of the Russian avant-garde, and parallels between the intentions expressed by modernists, on the one hand, and the total transformation of public life that was implemented by the Bolsheviks, on the other. The issue was not just the radicalisation of the aesthetics of the avantgarde during the Stalinist period, but also a logical phase in this type of aesthetics. Compared to avant-garde art, which created a new world in which the artist himself had no room, Socialist Realism had as its goal

38 Boris Groys, „The Art of Totality“, The Landscape of Stalinism: The Art and Ideology of Soviet Space, eds.Evgeniy Dobrenko, Eric Naiman (Seattle: University of Washington Press, 2011), 101. 
the creation not only of a new world, but also a new type of human being. Official and politically commissioned art and the practices of the avant-garde had, according to Groys, similar tendencies of semantic innovation. Socialist Realism and the avant-garde both implemented practices in the context of which the semantics of reality were changed. Both the avant-garde and Socialist Realism perceived the heritage of the past as nothing more than materials to be put to free use. ${ }^{39}$

Groys' vision of the relationship between the avant-garde and Stalinism was clearly impressive and while it caused several methodological questions which remained unanswered, such as the comparison of totalitarianism as a political phenomenon with the avant-garde as an artistic phenomenon, it provided evidence that avant-garde had an impact and even an ideological impact. This impact was conditioned because of the immanent power of avant-garde that came into sight because of its radical altering of visual language and visual power that dominated pictures. It appropriated and annexed previously existing ideologies, for example Marxism, and also produced its own ideologies and its own Weltanschauung.

\section{MODEL OF POTENTIAL VISUAL DOMINANCE (PROTO- IDEOLOGY MODEL)}

Although Ideology model of avant-garde art could be interpreted by Groys and others as a forerunner of Socialist Realism or even Stalinist totalitarian state, any affirmative mention of avant-garde art and even of Soviet avant-garde art was ruled out by Soviet authorities. However, Ideology model existed during all periods of Socialist Realism as an unspoken alternative choice and potentially possible model of relations between artistic and politic languages. It existed in the mode of a covert proto-Ideology model that emerged during the social optimism of the Khrushchev Thaw. The appearance of proto-Ideology model caused the crackdown of Moscow nonconformists at the late 1962 and the necessity of a cover-up of this emergence of proto-Ideology model reasoned the very term of the "Rough Style" to appear almost ten years later than those artistic expressions, which it had intended to designate, aroused. ${ }^{40}$

39 Groys, Gesamtkunstwerk Stalin, 58-71.

40 Laima Reihmane, „Divdesmitā gadsimta otrās puses grafikas izpētes problēmas“, Doma 6, ed.

Ilze Konstante (Riga, Latvijas Mākslas muzeju apvienība, 2000), 241-254. 
The "Rough Style" was marked as a compromise conception that had to reconcile certain efforts of emancipation of the visual language with extended dominance of a politically engaged text. The very term "Rough Style" was carried out while ousting other eventual conceptions that probably better characterized efforts of liberalisation of the artistic expression, for example, "Stilj Epochy" ("Style of the Age") or "Sovremennij Stilj" ("Contemporary Style"). ${ }^{41}$ Supposedly, from the point of view of the contemporaries, "Rough Style" idea was not relevant enough to display all complexity of stylistic developments of this period; rather, it could be seen only as a rhetorical technique intended to describe retrospectively a certain period of artistic events.

\section{MODEL OF NEGATIVE VISUAL DOMINANCE (POST-IDEO- LOGY MODEL)}

If we agree with Boris Groys, we also have to acknowledge that the decline of utopian and avant-garde modernism inside democratic societies was inevitable. The power of totality was so destructive that Western democracies otherwise would not have survived. Modernism was dismembered and commercialized but its appeals to freedom, social activity and artistic autonomy made both ends meet. The model of postmodern condition could not be described as simply dominated by visual language. Like in the case with post-Propaganda model, there was no more coherent and homogenous source of domination. The main driving force of post-Ideology model was not the dominance of visual but the fear of any signs of textual political domination. Post-Ideology model though did not deter political powers from manipulating art to achieve their goals. The best example was the exploitation of American Abstract Expressionism by CIA during the Cold War years to indoctrinate American values. ${ }^{42}$

At the same time it can be acknowledged that post-Ideology model was the most widespread way used by contemporary artists to express their political views and engage into social, civic and political activities. This was the main model of political engagement of artists

41 Georgij Kucherenko, Jesteticheskoe mnogoobrazie iskusstva socialisticheskogo realizma (Moscow: Sovetskij hudozhnik, 1966), 32.

42 M. J. Holler, „The Artist as a Secret Agent: Liberalism Against Populism“, The Economics of Transparency in Politics, Eds. Albert Breton et al. (Aldershot: Ashgate Publishing, 2007), 73. 
in most present Western societies during second half of $20^{\text {th }}$ century. The lost ideals of visual dominance were not replaced by new ones. The only struggle that could be afforded by contemporary artists was the struggle to preserve the modernist myth of autonomy of art and artists. Evidently, because skeptical discursive practices of post-Ideology model provided artists with tools suitable for the deconstruction of any ideology, it surfaced on the Soviet underground art scene with the appearance of Soc-Art in 1970s. However, post-Ideology model became the dominant model on the Soviet and Latvian art scene only in the post-totalitarian, this is, post- 84 period. Of-course, it was not the first time when post-Ideology model was introduced in Latvian art scene during $20^{\text {th }}$ Century. When avant-garde depleted its ideological power it was dismembered and commercialized and while artists, even certain Latvian modernists converted back to the means of realistic and mimetic expression they explored Realism not as a method but as a kind of citation that could be reinterpreted inside their visual discursive practices. These practices coexisted with the proto-Propaganda model manifesting the "Long Thirties", namely, a certain tradition of interrelations between the texts and art that continued in Latvian art space until 1948.

\section{MODELS OF SOCIALIST REALISM}

Proposed models of engagement allow an interpretation of certain periods of Socialist Realism as being conditioned by one or another dominant model. However, even a brief glance on Soviet art demonstrates that dominant models are accompanied by their predecessors or potential rivals. Regarding the necessity to reveal relations between dominant and rival models other logically geometric constructions of Aristotle's square would be applied. ${ }^{43}$ Considering an opportunity to adapt " $\mathrm{N}$ - opposition theory" proposed by Allesio Moretti a Logical Tetradecahedron could be chosen. ${ }^{44}$ It allows to extend the set of six models with six new

43 Andris Teikmanis, „The use of semiotic modelling as a research tool of art history“, Tartu Summer School 2011 - SEMIOTIC MODELLING, 22-26. august, http://www.ut.ee/SOSE/conference/summer_ school/2011/papers/Teikmanis_TSSS2011.pdf (accessed 6.11.2013).

44 Alessio Moretti, „Geometry for modalities? Yes: through n-opposition theory“, Aspects of Universal Logic. Selected Papers From the International Workshop on Universal Logic Held in Neuchatel, October 6-8, 2003 (Neuchatel, Universite de Neuchatel, Centre de Recherches Semiologiques, 2004), 102-145. 


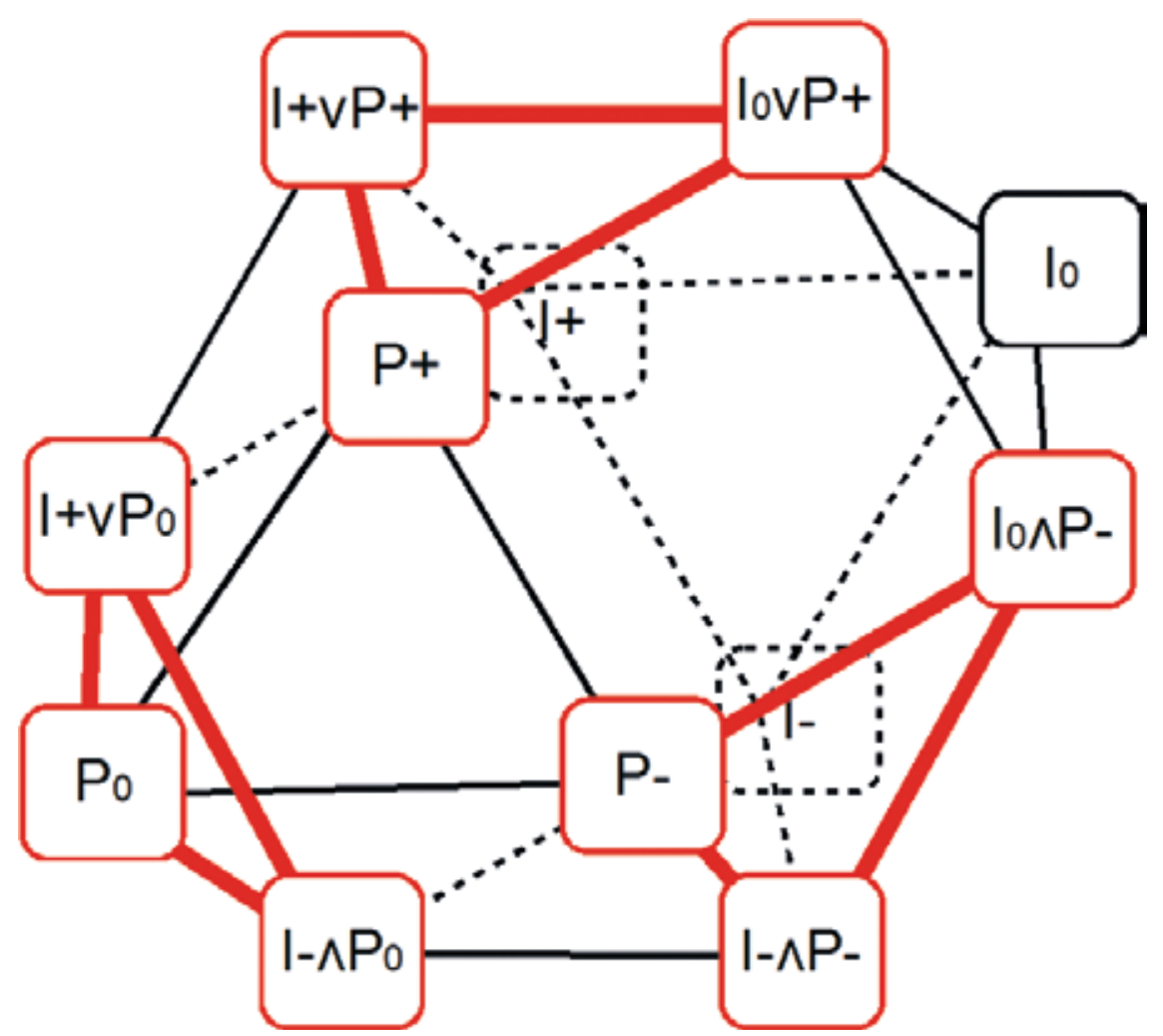

Fig. 2. The Semiotic Tetradecahedron of interaction between pictures and politics based on the adaption of Moretti's Logical Tetradecahedron

Six new combined categories: $\mathrm{I}^{0} \mathrm{vP}+-$ Disjunction of proto-Ideology and Propaganda models; $\mathrm{I}+\mathrm{vP}^{0}-$ Disjunction of proto-Propaganda and Ideology models; $\mathrm{I}-\Lambda \mathrm{P}^{0}-$ Conjunction of post-Ideology and proto-Propaganda models; $\mathrm{I}^{0} \Lambda \mathrm{P}--$ Conjunction of post-Propaganda and proto-Ideology models; I+vP+ - Disjunction of Ideology and Propaganda models; I- $\Lambda$ P- Conjunction of post-Ideology and post-Propaganda models

combined categories based upon disjunction and conjunction of proposed models.

These combined categories demonstrate that each simple model of engagement is logically tied in conjunction or disjunction with potential, positive or negative opposite models. The disjunction between an application of Propaganda model and positive or potential Ideology model provides the explanation of Anti-formalist position of Stalinists as conditioned by anxiety over visual power of images that will break subjugation of visual discourse to articulated ideology. The episode of the "Rough style", on the other hand, can be interpreted as a last 


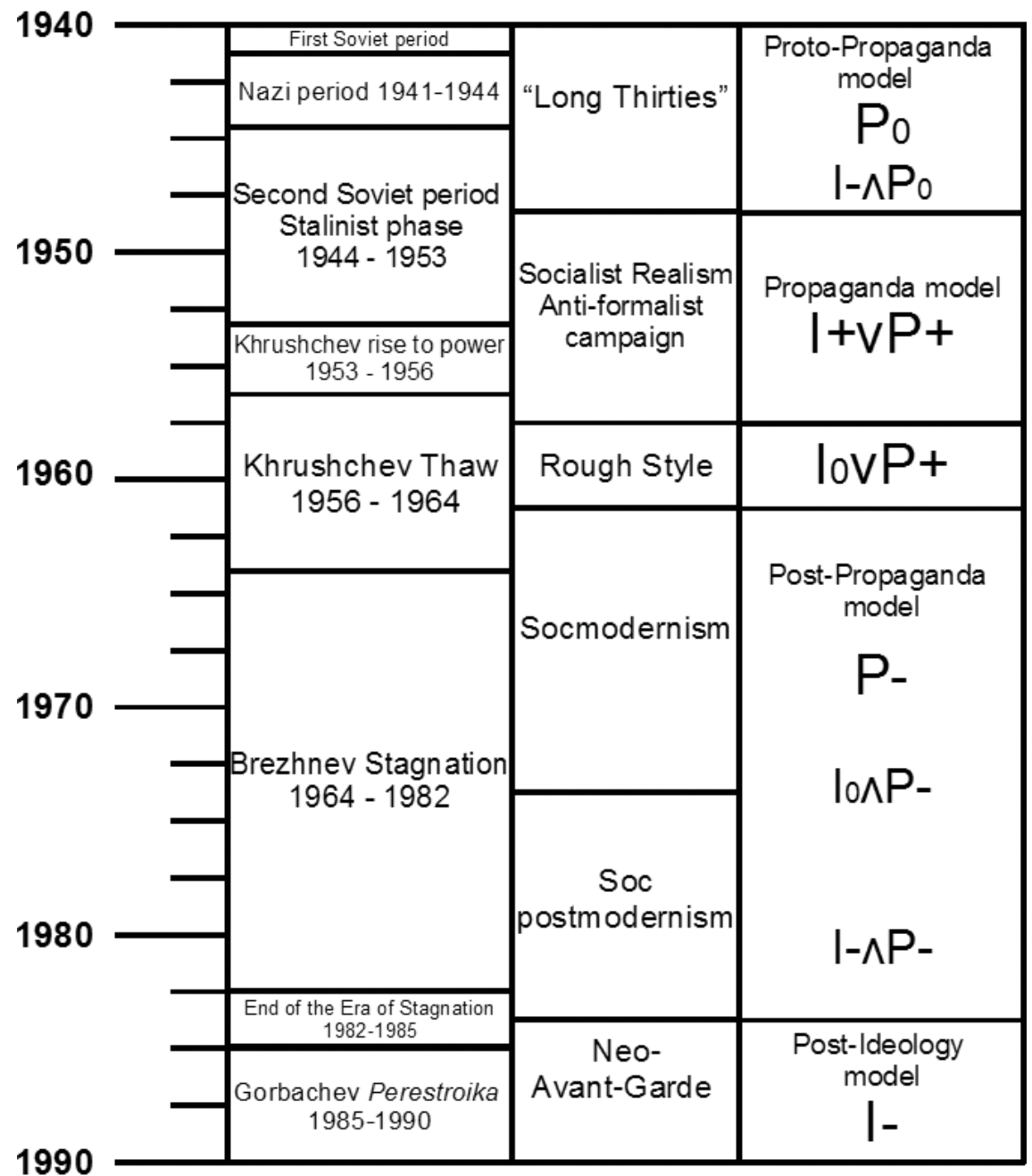

Fig. 3. Change of models of Socialist Realism

stand of the Propaganda model against possible rise of new, potential visual discourse. After the crush of the rising proto-Ideology model the Propaganda model evolved into the post-Propaganda model, which contrary to Propaganda model, coexisted with proto and post-Ideology models. This mode of coexistence with preceded and potential models that was represented by modern and postmodern artistic forms allowed 
an adaptation of new stylistic definitions of Socialist Realism art offered by Eduards Klavin,š: "Socmodernism" and "Socpostmodernism". 45

The application of models of Socialist Realism that provides the interpretation that certain periods of Soviet art might be described as conditioned by evolving interconnected models of engagement also allowed a new periodization of Soviet Latvian art according to the interrelated change of these models. The First Soviet period (1940-1941), the Nazi period (1941-1944) and beginning of the Second Soviet period (1944-1956) were examples of the coexistence of the proto-Propaganda model, which was resulted from endeavors of totalitarian powers to control art and artists, who still followed the post-Ideology model left behind by the "Long Thirties", namely, because of the inertia of artistic form. Full implementation of the Propaganda model resulted in a campaign against use of formal artistic components. Aspirations of liberalization during the Khrushchev Thaw conditioned the emancipation of artistic language. The episode of Soviet Art known as the "Rough Style" was a phase of transition from the Propaganda model into the post-Propaganda model. However, this phase was marked by the last disjunction between the Propaganda model and the rising proto-Ideology model. Inversely, the post-Propaganda model, which replaced the Propaganda model, coexisted with potential but the unimplemented proto-Ideology model and the accumulative presence of the post-Ideology model. Permutations of the Soviet Union during last years of stagnation and Gorbachev's Perestroika provided artists with opportunities to adopt globalised language of Neo-Avant-garde art that finally ensured the dominant position of the post-Ideology model.

\section{CONCLUSION}

Proposed models of Socialist Realism are based on the assumption that affairs between pictures and politics could be translated into relations of visual and verbal discourses. It allows an interpretation that interaction between textual and visual modes of communication had been interpreted and categorized as a set of models based on positive, negative or potential visual or textual dominance, and their combined categories.

45 Eduards Kḷaviņš, „Socreālisma mutācijas: socmodernisms un socpostmodernisms Latvijā“, Padomjzemes mitologiija (Riga: Latvijas Nacionālais mākslas muzejs, 2009), 102-113. 
The application of these models of Socialist Realism does not offer radically new interpretation of the Socialist Realism or periods of the Soviet Art. Rather, it makes available new tools and new framework of interpretation of the Socialist Realism and periods of the Soviet Art. Proposed approach contributes toward establishing a framework of interpretation and the declaration of models of the Socialist Realism.

At the same time, the categorization of Soviet art periods demonstrates that models of engagement were dynamically evolving from potential into active and passive stages while being connected with their potential rivalry models. Therefore, the proposed approach would be seen not only as having explanatory power of past but also as having potential of prediction of future relations between art and politics. The model of political engagement after the collapse of the Soviet Union and its satellites can be described as a conjunction of post-Ideology model and proto-Propaganda model. The same conjunction of both models existed in Western art for decades of postwar period. However, the rise of new media art in the middle of 1990s could be identified as the new proto-Ideology model marking the beginning of a new technological Avant-garde of $21^{\text {st }}$ century that still has not depleted its potential power. Advancement of information technologies will transform our modes of perception and establish a radically new Ideology model that will employ new visual discourses. They will emerge from modern visual technologies: 3D-cinema, 3D-television and 3D-graphical interface, virtual and augmented reality. In the same time, proto-Propaganda model is still hiding in the shadows of political activism of contemporary artists. The most obvious example of recent emergence of this model was the phenomena of so called "Obama Art". Although proto-Propaganda model may seem as a peripheral manifestation in the contemporary art, the destructive power of the new Ideology model will clear the path for a next Propaganda model. It will also entail the appearance of next versions of politically motivated theories that will justify political engagement of art. 
Andris Teikmanis: Toward Models of Socialist Realism Keywords: Soviet art, Latvia, Socialist Realism, political ENGAGEMENT, SEMIOTIC MODELS

Abstract:

Soviet Union collapsed in 1991 leaving behind the necessity to interpret and analyze practices of political engagement of art, Socialist Realism theory and method and Soviet art heritage. The aim of this research was the definition and elaboration of models of engagement used by the Soviet power. These models were intended as tools that allowed interpretation and categorization of particular periods of Soviet art ensuring political neutrality of these interpretations. These conditions determined the use of modes of interaction between political textual discourses and visual discourses of images rather than the content of politically engaged pictures as foundation of projected models. This allowed not only to interpret particular aspects of the Socialist Realism and categorize particular aspects of Latvia Soviet art periods, but also to declare some broader considerations about relations between art and politics.

Cv:

Andris Teikmanis is associated professor and Vice-Rector of Art Academy of Latvia. Teikmanis defended his doctoral thesis „Semiotic of Relations between Art and Politics. Interaction between Visual and Verbal Messages in Latvian Soviet Period Painting" in 2010. 
